\title{
OPTIMALISASI TAMAN BACA WARGA UNTUK MENDUKUNG PROSES PEMBELAJARAN ANAK DI KENDUNG SEMEMI SURABAYA
}

\author{
Yulis Setyowati \\ Universitas Wijaya Putra \\ yulissetyowati@uwp.ac.id
}

\begin{abstract}
Abstrak
Kegiatan pemberdayaan ini dilaksanakan tepatnya di Kendung RT 03 RW 06 Kelurahan Sememi Kecamatan Benowo Kota Surabaya bertujuan utamanya untuk mengaktifkan kembali fungsional perpustakaan mini yang sudah ada semenjak 2015 tetapi tidak didayagunakan oleh warga setempat. Selain itu kegiatan ini bertujuan memberikan ruang belajar dan bermain bagi anak-anak sehingga mampu mendukung tumbuh kembang mereka. Pemberdayaan perpustakan kampung mini ini dilakukan dengan metode pelatihan karang taruna salah satunya adalah pelatihan pengelolaan perpustakaan, pendampingan serta penguatan karang taruna dalam melaksanakan kegiatan serta pembimbingan untuk mencari jaringan untuk meningkatkan jumlah buku koleksi perpustakaan mini. Beberapa bentuk kegiatan pemberdayaan ini berupa menataan kembali buku koleksi, penyegaran katalog, penambahan buku serta pelatihan karang taruna untuk mengelola perpustakaan yang lebih menarik warga setempat khususnya anak-anak. Kegiatan lainnya adalah mengiatkan program-program untuk anak-anak seperti membaca buku cerita bergambar, mewarna, menggambar, bermain puzzle, bermain dengan dongeng, membuat komunitas belajar bersama, membuat media pembelajaran dari barang bekas, dan membantu Karang Taruna menemukan jejaring yang bisa mensupport penambahan koleksi buku. Dengan kegiatan pemberdayaan seperti diatas diharapkan tidak hanya mampu mendukung tumbuh kembang anak tetapi juga memberikan wadah Karang Taruna agar lebih aktif melakukan kegiatan yang biasanya hanya aktif pada peringatan Hari kemerdekaan 17 Agustus Negara Republik Indonesia
\end{abstract}

Kata Kunci : pemberdayaan, Taman Baca, tumbuh kembang, anak,

\section{PENDAHULUAN}

Taman Baca Warga telah banyak hadir di wilayah Kecamatan Sememi Kecamatan Benowo dan salah satunya adalah di Kendung RT 03 RW 06. Taman Baca yang berada pada wilayah RT 03 dan terleka di Balai RW 06. Taman Baca ini beroperasi setiap hari buka dari pukul 09.00 WIB sampai dengan pukul 15.00 WIB. Selain berfungsi sebagai Balai RW tempat dimana diadakan pertemuan warga setempat, balai ini juga berfungsi sebagai tempat dilaksanakannya PAUD seminggu tiga kali yaitu di pagi hari dilaksanakan setiap hari Selasa, Kamis dan Sabtu. Dengan sistem operasi yang hanya buka di pagi dari hari Senin sampai hari Jumat membuat pengunjung taman baca tersebut nyaris sepi setiap harinya. Pada saat jam operasional taman baca dibuka saat itu pula para anak-anak sedang menempuh pelajaran di sekolah. Jam tersebut juga bersamaan dengan jam kerja masyarakat pada umumnya. Sehingga Taman Baca ini tidak dapat berdaya guna secara maksimal karena pengunjung

$$
\text { Pendidikan }
$$


yang datang hanya terbatas pada para penghantar anak yang mengikuti PAUD ataupun warga yang akan mengadakan pertemuan di Balai RW tersebut. Nyaris warga yang tidak berkeperluan di balai RW 06 tidak memanfaatkan Taman Baca tersebut.

Bertolak dari permasalahan maka perlu dilaksanakan kegiatan yang mendayagunakan Taman Bacayang sudah ada sehingga lebih maksimal fungsinya. Sebagai wilayah yang terdapat banyak anak-anak usia sekolah kiranya program ini difokuskan pada kegiatan yang mendukung daya tumbuh kembang anak-anak.

Selain jam operasional yang tidak sesuai dengan kebutuhan para penggunanya, koleksi yang terdapat di Taman Baca ini tidak cukup untuk sebagai untuk bacaan anak-anak usia sekolah. Taman Baca ini lebih banyak mengoleksi pengetauan umum serta buku pelajaran untuk tingkat sekolah menengah atas serta majalah majalah orang dewasa. Setelah dilakukan observasi koleksi buku anak-anak yang terdapat hanya tidak lebih dari $20 \%$ dari koleksi yang tersedia.

Kemudian permasalahan selanjutnya adalah Buku koleksi yang tersedia tidak ditata dengan baik serta beberapa buku juga tidak terawat. Selain itu tidak adanya buku induk katalog membuat kesulitan jika ingin mengetahui secara keseluruhan daftar buku yang telah dimiliki oleh Taman Baca ini.

Sebagai perpustakaan mini Taman Baca Warga merupakan sumber pembelajaran yang kaya bagi anak-anak. Selain sebagai penyedia pusat atau sumber bacaan warga, Taman Baca bisa dimaksimalkan untuk pendukung utama dalam penyelenggaraan kegiatan warga khususnya kegiatan yang diperuntukkan anak-anak seperti membaca buku cerita bergambar, mewarna, menggambar, bermain puzzle, bermain dengan dongeng, membuat komunitas belajar bersama, membuat media pembelajaran dari barang bekas (Setyowati, 2018). Program-program inilah akan digiatkan dalam program Pengabdian Masyarakat.

Kementrian Pendidikan dan Kebudayaan menyatakan bahwa Taman Baca Masyarakat (TBM) adalah sarana atau lembaga pembudayaan kegemaran membaca masyarakat yang menyediakan dan memberikan layanan di bidang bahan bacaan berupa: buku, majalah, tabloid, koran, komik, dan bahan multimedia lain yang dilengkapi dengan ruangan untuk membaca, diskusi, bedah buku, menulis, dan kegiatan literasi lainnya, dan didukung oleh pengelola yang berperan sebagai motivator (Kemendikbud, 2013:4). Dari pernyataan tersebut bisa dikatakan Taman Baca Warga bisa berfungsi sebagai pusat layanan sosial yang menyediakan bahan bacaan serta pusat sumber informasi yang memotivasi masyarakat untuk berkegiatan yang lebih bermakna. TBM bisa menjadi tempat pemberdayaan masyarakat, dimana masyarakat dapat mengembangan kreatifitas mereka melalui program program yang diadakan oleh pihak pengurus TBM.

Salah satu ujuan didirikannya taman bacaan masyarakat menurut dari beberapa tokoh masyarkat adalah untuk menumbuhkan dan meningkatkan daya kreasi, prakarsa dan swadaya masyarakat. Daya kresi, prakarsa dan swadaya masyarakat bisa diwujudkan dengan pemberdayaan masyarakat yang berupa pelaksanaan program-program yang menunjukkan kemandirian dan kreatifitas warga. Selain itu juga bertujuan menunjang pelaksaan wajib belajar serta semangat masyarakat dalam mengakses informasi yang bersifat rekreatif dan edukatif.

Bisa dikatakan bahwa tujuan didirikannya TBM yaitu untuk meminimalisir masyarakat yang buta aksara yang bisa diartikan secara luas hanya pada kemampuan membaca saja tetapi juga buta tentang informasi, tentang isu-isu yang sedang terjadi ataupun tentang kebutaan masyarakat akan kejadian sosial di sekitarnya.

Salah satu fungsi Taman Bacaan Masyarakat menurut Kemendikbud menyebutkan sebagai media untuk penambahan wawasan, juga beberapa keterampilan praktis yang bisa dipraktekkan setelah membaca, misalnya praktek memasak, budidaya ikan dan sebagainya. Selain itu Taman Bacaan juga bisa sebagai tempat rekreasi-edukasi. Dengan bukubuku fiksi dan non fiksi yang disediakan oleh pihak TBM, diharapkan dapat memberikan hiburan yang mendidik dan menyenangkan.

Kegiatan pemberdayaan yang dimaksud di konteks kegiatan ini mengandung arti mengadakan serangkaian kegiatan untuk memperkuat keberdayaan keterampilan dan pengetahuan yang sudah dimiliki warga setempat untuk memaksimalkan fungsi Taman Bacaan. Kegiatan pemberdayaan Taman Baca ini juga mendukung program pemerintah yang diatur dalam UndangUndang Republik Indonesia Nomor 20 tahun 2003

$$
\text { Pendidikan }
$$


tentang system Pendidikan Nasional pasal 26 ayat 4 yang berbunyi bahwa satuan pendidikan non formal terdiri atas lembaga kursus, lembaga pelatihan, kelompok belajar, pusat pendidikan non formal yang terdiri atas lembaga kursus, lembaga pelatihan, kelompok belajar, pusat belajar masyarakat, majelis taklim, serta satuan pendidikan yang sejenis.

\section{METODE}

Tujuan kegiatan ini adalah untuk membantu pemberdayaan dan memaksimalkan fungsi Taman BacaWarga sebagai perpustakaan di Kendung RT 03 RW 06 untuk mendukung daya tumbuh kembang anak-anak di wilayah tersebut. Kegiatan Pemberdayaan ini dilaksanakan selain untuk memperkuat pertumbuhan anak-anak juga untuk meningkatkan keterampilan warga baik orang dewasa, dan remaja agar lebih terampil mengelola Taman Baca yang sudah ada.

\section{a. Pendampingan}

Bentuk pendampingan yang dilaksanakan dalam kegiatan ini dilakukan secara langsung kepada warga setempat. Pendampingan tersebut termasuk diskusi ataupun brainstorming, upaya - upaya untuk peningkatan keterampilan soft skills tentang pengelolaan dan memaksimalkan Taman BacaWarga yang ada, pendampingan pengelolaan Taman BacaWarga, serta pendampingan kader pengiat program pemaksimalan Taman Bacayaitu Karang Taruna.

b. Pelatihan Pengelolaan Taman BacaWarga dan Pemberdayaan Masyarakat yang memaksimalkan Taman Bacaan. Pelatihan ini juga berkaitan dengan pendampingan cara mengelola Taman Bacawarga yang sudah tersedia. Selain itu pendataan dan pembuatan data base mengenai daftar buku yang sudah dimiliki oleh Taman Bacaini juga dilakukan. Kemudian akan ada struktur organisasi pengurus Taman Bacawarga, serta akan terbitnya jadwal piket petugas Taman Bacawarga beserta jam operasional. Untuk mengevaluasi Taman Bacawarga ini diperlukan pencatatan jam kunjungan dan jumlah buku yang telah dipinjam ataupun dibaca oleh pengunjungnya. Selain itu akan ada daftar buku, jumlah buku beserta jenis koleksi buku yang sudah ada di Taman Bacawarga.

\section{c. Penyegaran Taman BacaWarga}

Taman Bacayang sudah waktunya disegarkan lagi koleksi bukunya serta ditata ulang pengelolaannya.

\section{HASIL DAN PEMBAHASAN}

\section{A. OPTIMALISASI TAMAN BACAAN}

Pada pembahasan sebelumnya dijelaskan kondisi Taman BacaWarga yang bisa dikatakan tidak berkembang dan jalan ditempat dikarenakan koleksi buku tidak bertambah, kurang seriusnya pengelolannya serta buku yang tidak mempunyai katalog maupun tidak terawatt dengan baik. Untuk itu program yang dilaksanakan untuk Taman Bacatersebut meliputi:

a. Katalogisasi

Setelah dilakukan survey terhadap keadaan Taman Bacaditemukan bahwa Taman tersebut memiliki katalog yang tidak terkini yang artinya katalog yang ada terakhir diperbarahui 2 tahun yang lalu. Dengan kondisi katalog yang tidak diperbarui otomatis banyak buku-buku yang terdaftar sehingga dalam kegiatan ini Tim Pengadian Masyarakat dari Universitas Wijaya Putra mendampingi proses perbaruan katalog. Proses pendampingan ini meliputi membimbing kader Karang Taruna untuk mendata kembali buku-buku yang dimiliki oleh Taman Baca kemudian menginput kedalam katalog di dalam program excel dengan memberikan buku seri induk dan pengelompokannya sehingga buku tersebut mudah diakses dan dikenali.

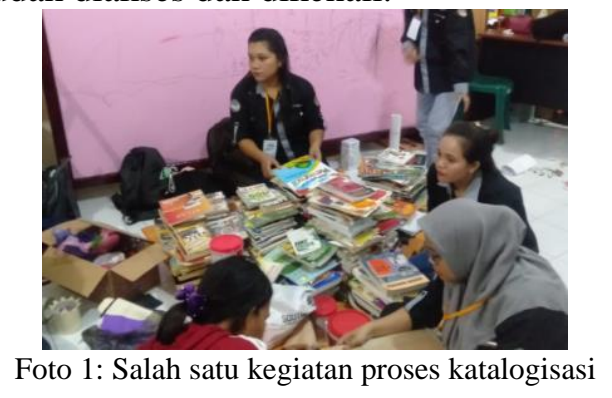

b. Penyegaran Buku

Penyegaran yang dimaksud adalah pemilihan buku yang layak ditampilkan dikoleksi Taman Baca. Pemilihan ini Pendidikan $\quad 886$ 
berdasarkan keadaan secara fisik buku tersebut seperti jumlah halaman, apakah masih lengkap atau banyak yang sudah berkurang, kemudian juga dengan cover buku, jilidan buku dan keadaan tinta buku tersebut. Jika buku tersebut sudah banyak halaman yang hilang, dan keadaannya koyak maka buku tersebut akan ditarik dan diganti dengan yang baru. Jika keadaan buku tersebut masih dibisa diperbaiki seperti jilidannya sudah tidak bagus maka dilakukan jilid ulang, penggantian sampul buku, dan penempelan nomer katalog buku.

Dari hasil observasi koleksi yang sudah dilakukan oleh Tim ditemukan terdapat 50(lima puluh) buku yang sudah tidak layak ditampilkan lagi karena kondisinya sudah tidak terjilid dengan baik, banyak halaman yang sudah hilang dan beberapa halamannya sudah sobek. Selain itu terdapat hampir 100 (seratus) buku yang sudah waktunya disampul ulang, diperbaiki penjilidannya, serta diberikan nomer katalog yang sudah rusak.

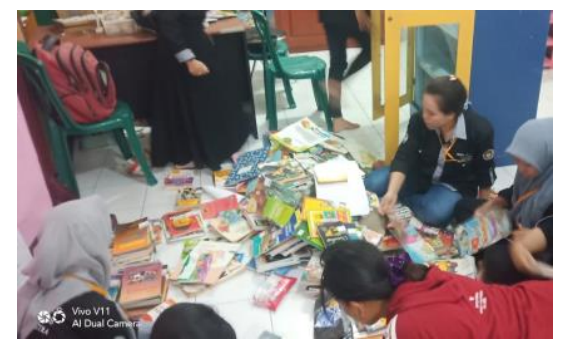

Foto 2: Proses pemilihan buku yang harus diganti sampul atau diperkuat jilidannya

c. Pembuatan Buku Sirkulasi

Buku sirkulasi ini mencatat peminjaman buku yang dikeluarkan oleh Taman Bacaan. Buku ini mencakup pelayanan yang diberikan oleh Taman Bacasalah satunya adalah pelayanan peminjaman buku. Meskipun Taman Bacaini sudah memiliki buku sirkulasi akan tetapi buku tersebut dalam kondisi yang tidak terawat dan tidak digunakan dalam artian setiap peminjaman sering kali tidak dicatat dalam buku tersebut.

d. Penambahan Koleksi Buku
Tim pelaksana Pengabdian Masyarkat memberikan masukkan agar koleksi yang sudah dimiliki ditambah. Untuk itu pengelola didampingi dan diarahkan untuk menemukan link, instansi, lembaga dan pihak-pihak yang bisa menambah koleksi buku yang ada. Dalam ini Tim pengabdian dari Universitas Wijaya Putra selain mendampingi pembuatan proposal kami juga mendampinginya untuk menyampaikan proposal tersebut ke pihak terkait sekaligus melakukan tindak lanjut setelah proposal tersebut diterima oleh instansi terkait.

e. Pelatihan dan pendampingan Pengelolaan Taman Baca

Ketika tujuan, peran Taman Baca sudah berjalan dengan baik maka peran dan fungsinya Taman Baca tersebut sudah dijalankan sesuai dengan tata kelolanya. Sistem pengelolaan buku merupakan strategi yang dijalankan dengan bijak agar Taman Baca tetap dapat berlangsung dan bertambah koleksinya.

Sedangkan manajemen koleksi merupakan area kunci dari tanggung jawab seorang pengelola taman bacaan. Koleksi bisa didefinisikan sebagai bahan pustaka atau sejenisnya yang dikelola dan diolah dengan cara tertentu. Seperti yang sudah disampaikan di paragraph sebelumnya kesuksesan Taman Baca terlelak pada system manajemen koleksi buku yang dimiliki. Hal ini disebabkan karena koleksi buku yang sudah dimiliki bisa saja rusak, dan bahkan hilang tanpa tata kelola yang baik. Selain itu tanpa pengelolaan yang baik koleksi buku tersebut akan hanya menjadi tumpukan buku yang tiada bermakna hanya sebuah tumpukan kertas dan barang yang tidak terpakai.

Koleksi-koleksi tersebut butuh untuk dirawat, didata dan digunakan secara maksimal. Untuk program kegiatan ini yang sudah dilaksanakan dalam hal pengelolaan koleksi yang ada adalah penggadaan atau 
penambahan koleksi dengan membuat proposal yang diajukan ke institusi yang dimungkin akan memberikan penambahan koleksi, penataan ulang pengelolaan koleksi investarisasi, pelabelan, pengklasifikasian buku, penyegaran buku, dan pelatihan pengelolan buku koleksi yang lebih efektif sesuai dengan yang dibutuhkan oleh masyarkat setempat. Yang perlu ditekankan dalam pengelolaan buku tersebut adalah kesungguhan pengelola Taman baca tersebut sehingga koleksi yang ada mampu memberikan manfaat yang bermakna dan arti. Pengelola Taman Baca harus dipahamkan bahwa Taman Baca yang mereka kelola harus mampu membuat fungsinya menjadi nyata dan dekat dengan kebutuhan masyarakat. Pada dasarnya Taman Baca memiliki fungsi utama yakni fungsi pendidikan, informasi, dan rekreasi. Taman Baca merupakan mitra utama kegiatan belajar masyarakat. Fungsi Taman Baca adalah menyediakan koleksi yang mampu menunjang proses belajar masyarakat. Bukan saja koleksi buku teks tetapi juga buku penunjang yang sifatnya lebih memberi warna pada buku teks. Sebanyak apapun koleksi yang dimiliki oleh Taman Baca belum bisa dimanfaatkan/ didayagunakan oleh masyarakat apabila koleksi tersebut belum diolah sehingga siap disajikan kepada para penggunanya. Pengelolaan koleksi yang baik akan menentukan sukses tidaknya sebuah program taman bacaan. Karena tanpa dikelola dengan baik, maka koleksi akan tetap menjadi kumpulan atau tumpukan buku yang tidak bermakna. Pengolahan bahan pustaka merupakan ujung tombak penyediaan bahan bacaan yang cocok dan tepat bagi para siswa. Langkah-langkah pengolahan bahan pustakan cukup rumit dilakukan, apa lagi kalau dilakukan oleh orang yang belum memahami prinsipprinsip pengolahan bahan pustaka. Karena pengolahan bahan pustaka harus sesuai dengan prosedur yang standar. Prosedur pengolahan dimulai dari inventarisasi koleksi, pengklasifikasian koleksi, mengideks koleksi, pengkatalogan koleksi, pembuatan akribut buku, dan seterusnya. Salah satu langkah pengolahan bahan pustaka yakni klasifikasi bahan pustaka. Klasifikasi yang diterapkan di pusat informasi dan Taman Baca didefinisikan sebagai penyusunan sistematik terhadap buku dan bahan pustaka lain atau katalog atau entri indeks berdasarkan subjek, dalam cara paling berguna bagi mereka yang membaca atau mencari informasi. Dengan demikian, klasifikasi berfungsi ganda, yaitu (1) sebagai sarana penyusunan bahan pustaka di rak, dan (2) sebagai sarana penyusunan entri bibliografis dalam katalog tercetak, bibliografi dan indeks dalam tata susunan sistematis. Sebagai sarana pengaturan bahan pustaka di rak, klasifikasi mempunyai dua tujuan yaitu: (1) membantu pemakai mengidentikkan dan melokalisasi sebuah bahan pustaka berdasarkan nomor panggil, dan (2) mengelompokkan semua bahan pustaka sejenis menjadi satu.

Point - point diatas adalah prinsip dasar yang harus dipahamkan dan prinsip-prinsip tersebut yang diutamakan dalam hal pelatihan yang sudah terlaksana.

\section{B. PEMBELAJARAN INTERAKTIF}

a. Membaca Buku Cerita Bergambar dan menceritakannya kembali

Seperti yang sudah dijelaskan di paragraph bahwa Taman Baca yang berada di RT 03 RW 06 dioptimalisasikan untuk mendukung pembelajaran dan salah satu kegiatan tersebut adalah kegiatan membaca buku cerita bergambar dan kemudian menceritakannya kembali. Kegiatan bercerita ini bisa dalam bercerita secara lisan ataupun bisa dalam tulis.

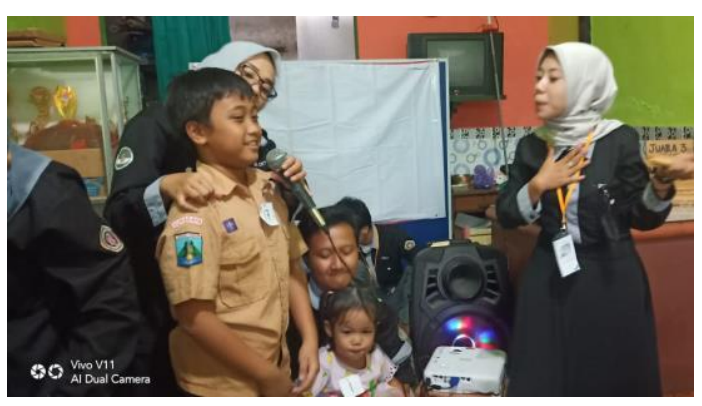


Foto 3: Setelah membaca buku cerita bergambar kemudian dilanjutkan dengan menceritakannya dalam lisan

b. Mewarna \& Mengambar bersama

Kegiatan yang selanjutnya adalah mewarna dan menggambar. Untuk mewarna ditujukan untuk anak-anak yang berusia dibawah 5 (lima) tahun dan kegiatan yang mengambar. Tema dari kegiatan menggambar dan mewarnai diambil dari hal-hal yang sangat dekat anak-anak seperti permainan, binatang, dan yang lainnya.

c. Menonton Film dan mencerikannya kembali

Kegiatan ini hampir sama dengan kegiatan bercerita kembali di sub bagian sebelumnya, yang membedakannya adalah sumber bahan cerita. Untuk kegiatan kali ini sumber bahan ceritanya adalah film. Anak-anak dikumpulkan kemudian diputarkan film anak-anak setelah mereka menonton mereka diminta untuk bercerita kembali dengan lisan dan bisa dengan dalam bentuk tulisan.

d. Bermain puzzle

Selain koleksi buku cerita pendek dan yang lainnya taman baca yang berada di wilayah RT 03 RW 03 juga memiliki permainan puzzle yang cukup banyak. Puzzle ini diharapkan mampu menambah kegiatan yang lebih bermakna dan memicu kreatifitas anak-anak.

\section{KREASI MEDIA PEMBELAJARAN}

a. Membuat angka dari karton bekas

Kegiatan yang lainnya adalah mendayagunakan karton bekas untuk untuk media pembelajaran.

b. Membuat alat tulis dari sampah kering Anak-anak juga dibimbing untuk memanfaatkan sampah kering agar lebih berfungsi seperti pembuatan tempat alat tulis, jadwal pelajaran dan lain sebagainya

c. Berkreasi dengan barang yang tidak digunakan lagi.

\section{KESIMPULAN}

Secara keseluruhan pelaksanaan Pengabdian Masyarkat ini yang bertema Optimalisasi Taman Baca Warga untuk mendukung proses pembelajaran anak berjalan dengan sangat baik, lancar dan sesuai dengan apa yang diharapkan. koleksi sudah di tata dan dikelola dengan sederhana namun dapat mempermudah proses pelayanan. Selain itu, para pengelola dalam hal ini Karang Taruna sudah memiliki kemampuan untuk mengelola koleksi secara sederhana dan pelayanan taman bacan. Kegiatan pembelajaran yang berbasis optimalisasi Taman Baca juga mampu memberikan nuansa tersendiri bagi anak-anak serta masyarakat sekitar. Kegiatan pembelajaran yang difokuskan kepada anak ini perlu digiatakan secara berkala agar tetap terjaga dan memberikan dampak yang jauh lebih mengena terhadap perkembangan anak-anak. Kedepannya diharapkan partisipasi warga agar lebih intens dan lebih proaktif agar kegiatan yang serupa bisa memaksimalkan hasilnya.

\section{REFERENSI}

Direktorat Pendidikan Masyarakat, D. P. D. P. P. (2008). Konsep Taman Bacaan Masyarakat Pendidikan Nasional. Jakarta

Depdiknas. Direktorat Pendidikan Masyarakat, D. P. D. P. P. (2009). Keaksaraan dalam Wacana Global: Media Komunikasi Pendidikan Keaksaraan (Aksara). Jakarta:

Dinas Pendidikan dan Kebudayaan. Direktur Jenderal Pendidikan Anak Usia Dini, Nonformal, dan I. (2012). Petunjuk Teknis Pengajuan dan Pengelolaan Taman Bacaan Masyarakat (TBM) Ruang Publik. Jakarta:

Kementerian Pendidikan dan Kebudayaan. Djohani, R. (2003). Partisipasi, Pemberdayaan, dan Demokratisasi Komunitas: Reposisi Participatory Rural Appraisal (PRA) dalam Program Pengembangan Masyarakat. Bandung: Studio Driya Media. Gong, Gol A.;

Irkham, A. I. (2011). Gempa Literasi: Dari Kampung untuk Nusantara. Jakarta: Gramedia Pustaka Utama.

Menteri Pendidikan Nasional R.I. Undang-Undang Republik Indonesia Nomor 20 Tahun 2003 tentang

Pendidikan 
Sistem Pendidikan Nasional (2003). Jakarta

Menteri Pendidikan Nasional R.I. Menteri Pendidikan Nasional R.I. Menteri Pendidikan Nasional No. 48 Tahun 2010 mengenai penguatan dan perluasan (2010). Jakarta: Menteri Pendidikan Nasional R.I.

Saepudin, E. (2016a). Literasi Media Bagi Guru Paud Di Kecamatan Cicalengka. Dharmakarya, (1)

Saepudin, E. (2016b). Tingkat Budaya Membaca Masyarakat (Studi Kasus Pada Masyarakat Di
Kabupaten Bandung). Jurnal Kajian Informasi

Setyowati, Yulis. 2018. Empowering Community Literasi Activties as wise solution to enhance soft and hard skill at Kendung Surabaya. Abdiku: Jurnal Pengabdian kepada Masyarkat STKIP Bangkalan Madura. Volume 1 No 1. http://jurnal.stkippgribkl.ac.id/index.php/Abdiku/article/view/518/282 